\title{
Evolution and Modernization of Islamic Education in Minangkabau
}

\author{
DOI 10.18196/AIIJS.2020.0114.82-98
}

\begin{abstract}
ALFURQAN
Social Science Faculty, Universitas Negeri Padang

Correspondence Email: alfurqan@fis.unp.ac.id
\end{abstract}

\begin{abstract}
Surau is an Islamic educational institution that is the prototype of other Islamic educational institutions in Minangkabau. Historically, the existence of surau began to decline due to modernization, which permeated the Islamic world. The evolution of the Islamic education system from halaqah to classical, changes in curriculum, levels in the world of education, mixing of Islamic education with basic colonial lessons and so on are the effects of modernization and the development of the technology industry in the early 20th century and the millennial era today. The evolution of Islamic education in Minangkabau is caused by several factors, including the modernization of ideology and the influence of culture from other regions, the developing system of government, and the rapid advances in industrial technology. The method used is library research with historical and philological approaches. Keywords: Islamic education, evolution. Minangkabau
\end{abstract}

\footnotetext{
ABSTRAK

Surau merupakan lembaga pendidikan Islam yang merupakan prototipe dari lembaga pendidikan Islam lainnya di Minangkabau. Secara historis, keberadaan surau mulai menurun akibat modernisasi yang merambah dunia Islam. Evolusi sistem pendidikan Islam dari halaqah ke klasik, perubahan kurikulum, jenjang dunia pendidikan, pencampuran pendidikan Islam dengan pelajaran dasar kolonial dan sebagainya merupakan efek dari modernisasi dan perkembangan industri teknologi pada awal abad 20. abad dan era milenial saat ini. Evolusi pendidikan Islam di Minangkabau disebabkan oleh beberapa faktor, antara lain modernisasi ideologi dan pengaruh budaya dari daerah lain, sistem pemerintahan yang berkembang, serta kemajuan teknologi industri yang pesat. Metode yang digunakan adalah studi pustaka dengan pendekatan sejarah dan filologi.

Kata Kunci: Evolusi, Minangkabau, Pendidikan Islam
} 


\section{INTRODUCTION}

The history of Islamic education in Minangkabau began in the 17th century after the return of Sheikh Burhanuddin from studying in Aceh and establishing an education center, Surau. Surau is the first Islamic education base and institution in Minangkabau. Surau had produced many ulama in the Minangkabau archipelago, and become famous far from the Minangkabau region, such as Malaysia, Singapore, and even the Middle East. Some examples are Sheikh Ismail al-Minangkabawi, Sheikh Thaher Jalaluddin, Sheikh Ahmad Khatib al-Minangkabawi, Sheikh Janan Thaib Bukittinggi and so on'.

In Minangkabau, Islamic education in Surau is considered a traditional Islamic education because education in Surau has not yet agreed with modernization, such as the madrasa in Minangkabau and Islamic boarding schools in Java. An education system that still teaches Islam without general knowledge such as in schools and madrassas and pesantren today².

The originality of Islamic education in Minangkabau began to change from the beginning of the 20th century, which was considered a renewal and enlightenment called the renaissance. ${ }^{3}$ The process of change towards modernization is the renewal of modern science and technology in the western world, which entered the Islamic world in the 19th century. In Islamic history, it is considered as the beginning of modernization. Islamic education, which was initially traditional, began to be tampered with and led to modern education in accordance with the times and the development of science. Old ideas that are considered irrational, customs, institutions, and so on try to be adapted to the advancement of modern science and technology. It has been realized with the emergence of educational institutions such as madrasahs and schools in Minangkabau, including Sumatra Thawalib Education institution in Padang Panjang and Adabiah School in Padang.

In 1909 M Abdullah Ahmad founded an educational institution in the form of a madrasah with the name Adabiah which made religious science education the subject matter. However, in 1915 Adabiah received subsidies from the government and changed to HIS under the name Hollandsh Malaiche School Adabiyah ${ }^{4}$. When the Adabiah school changed to HIS, Adabiah lost its identity as a Religious education school because the education system had been replaced so that Adabiah schools were not much different from schools established by the Dutch, which prioritized general material and did not teach Religious education. However, Adabiah schools try to maintain the main points of the values of Islamic teachings such as the Quran and Hadith even 
though general material dominates. The implementation of the education system made Adabiah considered a pioneer in the pattern of national education in Indonesia, which first combined general education plus religion and as a plus general religious education.

The Dutch government and educational institutions established by the Dutch influenced the strong foundation of the traditional education system coupled with the spirit of renewal that occurred in the early 20th century by Muslim reformers due to the development of western knowledge and technology that influenced the Islamic world and made the traditional Islamic education system more unsteady. In addition to the development of knowledge and influence of the west, the emergence of thoughts from Muslim reformers who think that the need for reform in the Islamic education system to be able to answer the challenges of colonialism and Christian expansion. ${ }^{5}$

Coupled with the influence of the increasingly advanced technology industry brought major changes to the world of education. The education system which initially only sat cross-legged, with technological advances and the influence of the western world education system that used benches, tables, and blackboards, then the education system including Islamic education also changed using these tools. Especially nowadays, the technology industry has become more rapid, the emergence of computer technology, android and so on has increasingly influenced the education system in Indonesia in general and Minangkabau in particular. This technology is also supported by the government to be applied to educational institutions that are developing in Minangkabau.

\section{TRADITIONAL EDUCATION SYSTEM IN MINANGKABAU}

Surau is a place of worship and the first Islamic educational institution in Minangkabau created by Burhanuddin. It is from Surau that all aspects of Islamic education are carried out, starting from religious learning through religious manuscripts to the practice of the learning. The process of Islamic education carried out by Sheikh Burhanuddin is not extreme, but it blends with the behavior and customs of the Minangkabau people. So that Surau is not purely teaching Islamic education, but also teaches about developing customs which will gradually be adjusted to Islamic law. This can be seen in some Minang philosophies in West Sumatera such as; adat basandi syarak, syarak basandi Kitabullah (custom is based on the Islamic legal tradition (syarak). It is on the basis of the Kitabullah, al-Quran), syarak mangato adat mamakai 
(syarak says; adat applies), adat basisampiang syarak batilanjang (traditional sideways wide open syarak).

From the philosophy used by the Minangkabau people, it can be seen that Islam has been embedded in the lives of people in Minangkabau. The society that has been understood as social order is a reality that consists of a set of behaviors for each pattern in the corridors of cultural order, customs, and traditions. Developing customs are also influenced by Islamic religious values and uphold customary and religious values. ${ }^{6}$ Therefore all customs must be returned to the law of God originating from the Quran and the Sunnah of the Prophet, namely the hadith, that is the meaning of adat basandi syarak, syarak basandi Kitabullah. In addition, whatever is considered to be in accordance with syarak (Islamic Shari'a) then that is what will be used by adat. This is the meaning of the philosophy of syarak mangato adat mamakai.

The books used in surau at the beginning are books that are commonly used in madrasah and traditional Islamic pesantren in Minangkabau. For example in Fiqih lessons, the books are commonly used by the Shafi' scholars, such as fathul qarib and Minhâj al-Thalibîn, Umm al-Barahain in Islamic theology (ushulal-din); Jalalain in the Qur'anic exegesis (Tafsir); and Matan al-Ajurumiyah and Matan Minâ' in the Arabic Grammar (Nahw). The books used in surau are considered to have a high level of use in madrasah and pesantren in the era of the 20th century AD so that some of the books used in the past are not used anymore in madrasah and pesantren in Minangkabau.

The system used in surau education in Minangkabau is not much different from the system used in traditional Islamic pesantren, such as: ${ }^{7}$

1. Wetonan; namely the kiyai or the shaykh reads the book in front of the students who also hold and pay attention to the same book. The santri only listens to the recital of the book that is read by the kiyai or the sheikh.

2. Sorogan; which is a private system where students come to the teacher and read the book in front of the teacher, also called review.

3. Mudhakarah; namely a kind of scientific meeting that addresses early issues such as; worship and creed as well as religious issues in general. This mudhakarah system has two ways, firstly the deliberation of fellow students to solve a problem through the existing books. It aims to train students to solve problems through books. Second, mudhakarah led by kiyai or sheikh to assess santri in solving problems, both in the form of books used and the skills of students in Arabic. 
In addition, surau has two models or two levels of religious education; first, basic level religious education, and secondly, deepening religious education. The basic level of religious education is for children aged 5-9 years with learning materials to read the Quran, Fiqih of Worship, Tajwid, and other basic knowledge of Islamic religion. Students who study in surau are fully handed over to teachers who teach. After they finished the study and wanted to deepen the study, the study will be continued at the Muslim cleric. Surau ulama is like Surau Sheikh Burhanuddin and Surau from Sheikh Burhanuddin's students who helped establish surau in his hometown after completing studies such as; Surau Sheikh Muhammad Natsir in Koto Tangah Padang, Surau Sheikh Buyuang Mudo Puluik-Puluik in Pesisir Selatan, Surau Sheikh Abdurrahman in Bintungan Tinggi and so on ${ }^{8}$.

In addition to providing religious education, Surau also offers spiritual education for students through the tarekat path. Spiritual education is the planting of the love of God in the hearts of students, which makes him expect the blessing of Allah SWT. In every speech, action, attitude, and behavior, and stay away from things that cause God to be angry ${ }^{9}$. Spiritual education is also interpreted as an attempt to find a relationship with God through the process of education and training (riyadhah) so that one can meet and unite themselves with their Lord ${ }^{10}$.

Therefore Surau, which was founded by Sheikh Burhanuddin, is also famous for the center of the Syattariyah congregational genealogy in Minangkabau. ${ }^{11}$ It can be said that in general, surau in Minangkabau is now better known as surau tarekat compared to surau as a center of education because for the people today, Islamic education is identical to madrasah and pesantren.

Verker Pistorius in his article entitled En Zijn Invloed op de samenleving in de Padangsche Bovelanden (influence of ulama in Minangkabau society) recorded the surau which developed in Minangkabau along with the number of students until 1868 AD as follows: ${ }^{12}$

1. Surau Taram, around 1000 students.

2. Surau Koto Tuo, around 220 to 300 students.

3. Surau Cangkiang, around 400 students.

4. Surau Pasir, around 300 students.

5. Surau Laboh, Tanah Datar, around 200 students.

6. Surau Simabur, around 200 students.

7. Surau Padang Gantiang, Tanah Datar, around 100 students. 
8. Surau Pangean, around 100 students.

9. Surau Pie (Laras Salajoe), around 300 students.

10. Surau Muara Panas, around 100 students.

11. Surau Kota Hanau, around 200 students.

12. Surau Kasih, Larang Saniang Bakar, around 150 students.

13. Surau Singkarah, around 100 students.

14. Surau Calau (Sijunjung), around 300 to 400 students.

15. Surau Padang Sibusuk, around 150 students.

From Surau Islamic education, this is the birth of Minangkabau scholars and other educational institutions in Minangkabau. Some are known as Sufism experts in different parts of the world such as the famous Sheikh Ismail alMinangkabawi to the Middle East, Riau, Pakistan and Singapore, Sheikh Thaher Jalaluddin and Sheikh Jamil Jambek astronomers, Sheikh Ahmad Khatib alMinangkabawi who once held the position of mufti in the Middle East and Sheikh Janan Muhammad Thaib Bukittinggi the first Indonesian to obtain the 'natural title' from al-Azhar in 1924 and the founder of the al-Makkiyah Indonesian Madrasah in 1923 in the Middle East ${ }^{13}$. Everything from them is the result of surau education.

Some of the students who were born from surau education were then contaminated with modernist thoughts when they continued their studies in the Middle East, namely Saudi Arabia, which began education reformation at the end of the 19th century. This reform was caused by a meeting and mixing of Muslim regions of Saudi Arabia with Muslims in other areas around it through the Hajj so that the hajj and mass media are one of the significant factors in channeling the idea of educational reform. ${ }^{14}$

\section{EVOLUTION OF ISLAMIC EDUCATION IN MINANGKABAU}

a. Modernization of Education in the Early 20th Century

The modernization of Islamic education is due to the influence of the western world on the Islamic world and other cultural influences. The greatest possibility of outside cultural cultures and reformist thought permeated Minangkabau students who went to study in the Middle East. Hurgronje gives an overview of the social life in Mecca in the mid-19th century as a multicultural and dynamic life. Many community groups from various parts of the Islamic world interact, and there is a cultural exchange process. Hurgronje also provides information on the activities of the Nusantara community or also called the Jawi community as a very dynamic community. ${ }^{15}$ This dyna- 
mism has the potential to make the Jawi community one of them Minangkabau contaminated with reformist thoughts and other cultures in Mecca.

According to Caskel, two conditions must be met to make a civilization ready to accept cultural stimuli from the outside; first, an awareness that the person concerned is lacking; second, contact between the cultures involved must occur at more than one point and last for a certain period of time. These two things are clearly seen from the current wave of renewal in Minangkabau.

In history, Minangkabau experienced two Islamic reforms; the first stream is marked by the appearance of paderi. The emergence of paderi movement was due to the development of Islam, which was considered impure. The dissemination of Sufism-style Islam with motivational and tolerant persuasive steps carried out by ulama does provide fertile results for the spread of Islam in the Minangkabau. However, this method also has a negative impact on the purity of Islamic teachings with the implementation of things that are not in accordance with Islamic teachings such as cockfighting, gambling, and drinking. Quantitatively Islamization with tasawuf style can be said to be successful, but qualitatively, Islam that develops is still very far from true Islam. In addition, religious practices were mixed with aspects of the animist tradition that had developed in society before the entry of Islam, resulting in the impurity of the teachings of Islam. ${ }^{16}$

Some people from the Minangkabau who returned from the Middle East, such as Haji Miskin, Haji Abdurrahman, and Haji Muhammad Arif tried to purify the behavior of the Minangkabau people to the true Islamic Shari'a. Their renewal movement was due to their inspiration for the movements carried out by Wahhabis in the Middle East ${ }^{17}$.

The second stream is the emergence of a modernization movement of thought that was realized in the form of religious understanding and the education system. Scholars who have modern thought or reformed scholars are referred to as young people in Minangkabau, while scholars who maintain old traditions in religion are referred to as the elderly. Both of these groups have different understandings in several ways so that this religious polemic has become a golden age in terms of literacy in the Minangkabau. ${ }^{18}$

Four scholars became the foundation of the renewal or modernization movement in Minangkabau. They are H. Abdullah Ahmad, H. Abdul Karim Amrullah, Sheikh Jamil Jambek, and Sheikh Thaib Umar. The renewal of the Islamic education model in Minangkabau was initially started by $\mathrm{H}$. Abdullah Ahmad by opening an Islamic education institution in Surau Jembatan Besi, 
but did not last long and continued in Padang in 1909 with the name Adabiah School.

The establishment of Surau Jembatan Besi was not the result of the hard work of $\mathrm{H}$. Abdullah Ahmad himself, but also the results of the assistance of Sheikh Daud Rasyidi and his brother Abdul Lathif Rasyidi. Before moving to Padang, Abdullah Ahmad handed over the management of Surau Jembatan Besi to Sheikh Daud Rasyidi and Abdul Lathif Rasyidi. Then in 1912, M Abdul Lathif passed away, and to continue to carry out Islamic education at the Surau Iron Bridge Sheikh Daud Rasyidi asked H. Abdul Karim Amrullah to lead as well as foster Surau Jembatan Besi. ${ }^{19}$

Surau Jembatan Besi was later named after Thuwalib, as was followed by Surau in Parabek under the name Thawalib. This naming was an initiative of the students of Jembatan Besi and Parabek, and then this name was incorporated into Sumatra Thawalib. Based on that, it can be seen that Sumatra Thawalib is a manifestation of Surau Jembatan Besi and Surau Parabek. ${ }^{20}$ The change occurred in 1918 to the classical system, not halaqah as written by Imam Maulana:

At first, they taught in a halal way (sitting cross-legged around the teacher). As for Mr. Haji Abdul Karim Amrullah, who initially taught sitting crosslegged by him in Muara Pauh Sungai Batang Maninjau. He was often called by people to give recitations to Padang Panjang, located in Surau Jembatan Besi, namely one of his friends who were equally demanding in Mecca, namely Mr. Haji Abdullah Ahmad. Since there were many students in Padang Panjang, he wanted people to be able to divide the teaching day, which is a week on the Batang River and a week in Padang Panjang. By looking at the many students in Padang Panjang and looking at the importance of a long field, Mr. Haji Abdul Karim Amrullah decided to move to settle in Padang Panjang with his family in 1914 AD. In the beginning, he taught in Padang Panjang that was a way of being hindered as well. Four years later, namely in 1918 AD, his method of teaching was modern, namely by using tables and benches and given classes which were given the name of the school Thawalib. To strengthen and advance the school, an association was named, also called Sumatra Thawalib ${ }^{21}$.

In addition to changes in how to learn from halaqah to classical, Thawalib Sumatra also introduced class levels and diplomas, which began in the $1920 \mathrm{~s}^{22}$

Not only Thawalib, Adabiah also formed a model of the education system similar to Thawalib, namely classical and also introduced a system of hierar- 
chical levels based on the age of the child, not based on their estimated level of learning ability. Abdullah Ahmad's first formal textbook entitled Titian Kesoerga was the first attempt by Minangkabau people to produce a work that followed the principles of Islamic reformers and progress. The combination of Middle Eastern reformist pedagogy and the progressivism of the progress of European influence produced what is called Islamic modernism. ${ }^{23}$

Titian Kesoerga suggests weighing information obtained through the five senses, through external news, and through one's own thoughts to produce conclusions that are especially important to filter and consider war news. The war news written by Abdullah Ahmad as quoted by hadler was like the conflicts between Russia and Japan (1904) and between Italy and Turkey (1912) as events that were not directly related to the Minangkabau people but had an impact on political consciousness in West Sumatra. ${ }^{24}$

Not only educational institutions formed by Minangkabau people who are present in Minangkabau. Educational institutions established by colonialism with a combination curriculum between Islamic studies and other colonial standard subjects also developed in Minangkabau, such as the information provided by Nasution and Muhammad including Gouvernment Inlandsvhe School (native low school), Normal School (school teacher education) in Padang Panjang and Modern Islamietes School (Islamic teacher education school) in Bukittinggi. Modern Islamietes School applies a combination curriculum between Islamic studies and basic lessons in the colonial period, such as Dutch and English.

\section{b. Form of Post-Century Islamic Education}

The development of the technology industry or technological knowledge that is so rapid in the millennium is one of the factors eroding the existence of Islamic education in Minangkabau. The emergence of advanced technologies that aim to help alleviate human work has positive and negative impacts. The emergence of computers, internet networks, smartphones, and so on provides many features that are considered necessary to help humans.

The development of the technology industry or technological knowledge that is so rapid in the millennium century is one of the factors eroding the existence of Islamic education in Minangkabau. The emergence of advanced technologies that aim to help alleviate human work has positive and negative impacts. The emergence of computers, internet networks, smartphones, and so on provides many features that are considered necessary to help humans. 
Behind that goal, it turns out that technological advances also have a negative impact on the world of education, one of which causes laziness and immerses humans into the features provided. Indeed this technological advancement can also make it easier for humans in the teaching and learning process, such as giving a lot of information from various sources, facilitating teaching facilities, providing sources or books in part for free without having to go to the bookstore, providing religious and other material videos so. The use of Information and Communication Technology (ICT), better known as $I C T$, especially the use of computers and internet networks in learning, is a form of development in the technology industry. ${ }^{25}$

The positive impact above is not always a good thing for the world of Islamic education. The world of Islamic education, in addition to the understanding of religion, also requires noble human character in accordance with the Prophet as a role model and also needs religious practices to be studied. Education must be able to develop and touch all aspects, and potential possessed by students optimally, and strive to minimize the traits of limited human weakness appearing on the surface. Education is the most effective and strategic means to help people recognize themselves and understand the teachings of God. ${ }^{26}$

The purpose of Islamic education is the formation of personality based on Islamic religious laws towards the formation of the main personality in accordance with Islamic measures, besides that Islamic education is also an effort to guide and nurture students so that later after they complete Islamic education can practice it and make it as a way of life (Sadulloh, 2004). Based on a philosophical approach, Islamic education can be interpreted as a study of educational processes that are based on the values of Islamic teachings according to philosophical conceptions sourced from the holy books of the Quran and the Hadith of the Prophet Muhammad.

This goal can only be achieved through learning and getting used to the teachings. However, now due to technological advances, ordinary people have been able to study religion through videos tutorial provided via youtube. In addition, religious issues can also be sought from the sites provided. So that the function of the scholars as religious experts around them began to erode. Not only this, but it will also have the potential to mislead understanding and lead to divisions within the community because nothing will guide them to know the details of the furu'iyah that developed in Islam.

Islamic education is a basis for understanding and practicing Islamic teach- 
ings in human life. Islamic education is known and believed by its adherents as an educational activity derived from the philosophy of Islamic teachings with universal values contained in it, which always consider the development of human nature. ${ }^{27}$ This education is not only obtained from educational institutions, this education can also be obtained from the living environment, especially both parents. Parents in this matter also play an essential role in shaping the character of children, especially in providing them with spiritual education so that they can easily carry out a life that is moral and virtuous in accordance with Islamic law ${ }^{28}$.

The inner closeness between parents and children is one way to make them listen to each parent's words and follow the behavior of parents. In addition to the position of parents, it is crucial to foster and to educate their children. ${ }^{29}$ However, due to technological advancements aimed at helping human work, some parents use technological services to educate their children, such as using smart hafizh media to introduce their children to AlQuran recital and their muratals, so that they can remember and memorize them. Then the Quran and Iqra al-Qalam, which the Quran and Iqra can be recited by the pen used as the sensor. With this, it can be said that the function of parents and teachers as educators can be replaced by technology . $^{30}$.

Education of both parents is more pronounced than teachers in schools in this millennium because, at this time, Islamic religious education was only used as a comparative lesson in state schools in Minangkabau. In addition to minimal lessons, religious practices will also be carried out minimally, except for public schools based on madrasah new religious education will be more pronounced.

Therefore, madrasah and pesantren as the leading institutions of Islamic education that still exist in the millennium prevented their students from coming into contact with modern technology, so that their period of education was not disrupted and neglected by developing technology. Like being banned from carrying cellphones, musical instruments, and so on, they are also prohibited from watching TV media except on specified days. ${ }^{31}$

The drastic change in Islamic education in the millennium has generally occurred in urban communities because that is where the center of technological development, so that religious life is less visible in the city center. But in small areas, religious communities can still be seen today. This can be seen in one example of the Surau Simaung in Sijunjung, which still survives with 
its sura tradition, not Islamic pesantren and madrasahs. At present Surau Simaung is led by Tuanku A. Malin Bandaro and teacher of Islam in Surau. Tuanku A. Malin Bandaro provides free education and housing in Surau for children who have aspirations to become scholars ${ }^{32}$.

Learners taught by Tuanku A. Malin Bandaro is taught to socialize in religious matters to the Sijunjung community, so they are often called upon in marriage, marriage, and salvation by the villagers around Sijunjung, even once in a while, they are asked to go home by their parents to take care some things related to religion in their village. ${ }^{33}$

From this, it can be said that the real purpose of Islamic education is more visible and felt in small areas than in the city center, which becomes the touchpoint of modernization and object targets from the advancement of the technology industry. In this case, Zohar argues that the most fundamental crisis faced by modern humans is a spiritual crisis ${ }^{34}$. Modern humans who live today are in the periphery of their existence and move away from their center, while the center of their essence is spiritual. Goleman also argues that the last few decades are more appropriately called the melancholy era, which has a higher risk compared to the previous era in terms of suffering from severe depression and crippling lethargy of the soul. ${ }^{35}$

In addition, intellectual intelligence through the advancement of science and technology is one of the factors in the emergence of a spiritual crisis. That is because the values in human life prioritize the usability side, the abundance of materialistic, secularistic, hedonistic, and agnostic life that negates aspects of religious ethics, morality, and humanism. Based on this, it is clear that the advancement of the technology industry can erode humans rather than being religious, which is the goal of Islamic education. Therefore spiritual education as one of Islamic education must be revived and preserved at home and in educational institutions spread in Minangkabau because spiritual education in practice and theory is currently less taught in schools.

\section{CONCLUSION}

Based on the history of Islamic education in Minangkabau from the 17th century to the millennium today, Islamic education in Minangkabau has undergone a series of evolutions, both teaching media, and learning systems. Surau, as the first Islamic educational institution is a place of education that truly teaches Islam in depth and educates its students to live religiously in accordance with the Islamic Shari'a that they are studying. The close relation- 
ship between teacher and student when the teaching and learning process in surau becomes an advantage over the education system in surau.

Surau provides not only Islamic education in the form of understanding and practice but also supports Islamic education with students' spiritual intelligence to students through the tarekat. It aims to make students not only intelligent from thinking and understanding but also intelligent in the soul, in attitude, civilization, and morality.

Surau education began to evolve when the influx and development of renewal in the Islamic world were referred to as the modernization of Islam and the contact of Minangkabau people with various cultural cultures and modern thinking that developed in the Middle East. In addition, the developing (colonial) government system at the beginning of the 20th century was also a factor in the change in the model of Islamic education in Minangkabau. In addition to teaching about Islam, early 20th-century education also taught basic lessons from colonial countries such as Dutch, English, Geography, and so on.

Equally important in the evolution of Islamic education is the advancement in the technology industry, which began in the Western world in the early 19 th century. The progress of the technology industry is increasingly rapid in the millennium so that the industrial technology produced is not often a teacher for the community in understanding the teachings of Islam. This certainly can disrupt the actual pace of Islamic education and the existence of teachers as real educators. The relationship between teachers and students that forms the basis of early Islamic education in Minangkabau began to be replaced by advanced technology so that people can learn selftaught with the facilities provided by today's technology. The contribution of Islamic educational institutions in Minangkabau which tries to integrate imtaq and iptek (science and technology). So as to produce students who are able to dialogue with modernity, without eliminating the main task as the bearer of the moral mandate.

\section{ENDNOTES}

1 Teguh Hidayat, "Surau Syech Gadang Burhanuddin dan Surau Tinggi Calau", Kementerian Pendidikan Dan Kebudayaan Balai Pelestarian Cagar Budaya Sumatera Barat, 2016

2 M. Furqan, "Surau dan Pesantren Sebagai Lembaga Pengembang Masyarakat Islam di Indonesia (Kajian Perspektif Historis)”, 2019.

3 Lombard, "K. A. Steenbrink, Pesantrèn, Madrasah, Sekolah. Recente 
Ontwikkelingen in Indonesisch Islamonderricht, Meppel, 1974, 366 p."

4 Celarent, "The Modernist Muslim Movement in Indonesia, 1900-1942 by Deliar Noer."

5 Siregar, "Pondok Pesantren Antara Misi Melahirkan Ulama Dan Tarikan Modernisasi."

6 Furqan, "Islamic Education Values in Minangkabau Wedding Ceremony (Study of Traditional Mariage in Pauh, Padang, West Sumatera)."

7 Akhiruddin, "Lembaga Pendidikan Islam Di Nusantara."

8 Afdayeni, "Dinamika Sistem Pendidikan Islam (Surau) Minangkabau Pra Dan Pasca Pembaharuan."

9 Suhailah Zain al-'Abidin Hammad, Mas'uliyah al-Usrah fi Tahhin al-Syabab min al-Irhab, Lajnah al-ilmiyah li al-Mu'tamar al-Alami 'an Mauqif al-Islam min al-Irhab.

10 Abu Bakar Aceh, Pengantar Ilmu Tarekat: Kajian Historis tentang Mistik (Solo: Ramadhani, 1996), 42

11 Meigalia, "Oman Fathurahman, Tarekat Syattariyah Di Minangkabau; Teks Dan Konteks. Jakarta."

12 Zelfeni Wimra,"Keterlibatan Tuanku dalam Pergesekan Identitas Adat, Agama, dan Negara di Minangkabau". Analisis: Jurnal Studi Keislaman, 2020

13 Taufik Hidayat dan Chairullah, Bibliografi Karya Ulama Minangkabau Awal Abad Xx, Dinamika Intelektual Kaum Tua Dan Kaum Muda.

14 Yatim, Sejarah sosial keagamaan Tanah suci.

15 Roff, "C. Snouck Hurgronje, Mekka in the Latter Part of the 19th Century. Translated by J. H. Monahan. Leiden, E. J. Brill, Photomechanical Reprint, 1970, Pp. vi + 309, Index, Plates, Plans. 42 Guilders.”

16 Dobbin, Islamic Revivalism in a Changing Peasant Economy.

17 Dobbin.

18 Kahn, Questioning Modernity in Indonesia and Malaysia.

19 Daya, Gerakan pembaharuan pemikiran Islam.

20 Daya.

21 Abdul Manaf, "Naskah Sejarah Tarbiyah Islamiyah."

22 Abdullah, Schools and Politics.

23 Hadler; Sengketa Tiada Putus.

24 Hadler;

25 Engkizar dkk., "The Importance of Integrating ICT Into Islamic Study Teaching and Learning Process."

26 Harmonedi, "Pandangan Islam Terhadap Manusia : Terminologi Manusia dan Konsep Fitrah serta Implikasinya dengan Pendidikan"

27 Alfurqan, Konsep Pendidikan Islam Pondok Pesantren Dan Upaya Pembenahannya.

28 Aziz, "Pendidikan Spiritual Berbasis Sufistik Bagi Anak Usia Dini Dalam Keluarga."

29 Furqan dan Murniyeeti, "Profil Pendidik Dalam Lingkaran Terminologi AyatAyat Alquran."

30 Idawati \& Hesti, "Pengenalan Karakter Anak Usia Dini Melaui Smart Hafiz" In Prosiding Seminar Nasional STKIP PGRI Bandar Lampung, 2019 
31 Gumgum Gumilar, "Pemanfaatan Internet oleh SantriPesantren Modern (Islamic Bo arding School")". JIPSI-Jurnal Ilmu Politik dan Komunikasi UNIKOM, 4. 2015

32 Wawancara dengan Tuanku A. Malin Bandaro di Surau Simaung Sijunjung, Sabtu 6 Juli 2019

33 A. Malin Bandaro, Evolusi dan Modernisasi Pendidikan Islam di Minangkabau.

34 Zohar dan Marshall, Spiritual Intelligence.

35 Daniel Goleman, Emotional Intelligence: Why it Can Matter More Than IQ Learning, 24(6), 49-50

\section{REFERENCES}

A. Malin Bandaro, Tuanku. Evolusi dan Modernisasi Pendidikan Islam di Minangkabau, 6 Juli 2019.

Abdul Manaf, Maulana. "Naskah Sejarah Tarbiyah Islamiyah,” t.t.

Abdullah, Taufik. Schools and Politics: The Kaum Muda Movement in West Sumatra. Equinox Publishing, 2009.

Aceh, Abubakar. Pengantar ilmu tarekat: uraian tentang mystik. Tjerdas, 1964.

Afdayeni, Melia. "Dinamika Sistem Pendidikan Islam (Surau) Minangkabau Pra Dan Pasca Pembaharuan.” Jurnal Fuaduna/ : Jurnal Kajian Keagamaan Dan Kemasyarakatan 1, no. 1 (4 Januari 2018): 58-69. https://doi.org/10.30983/ fuaduna.v1i1.442.

Akhiruddin, Km. "Lembaga Pendidikan Islam Di Nusantara.” TARBIYA: Jurnal Ilmu Pendidikan Islam 1, no. 1 (18 April 2015): 195-219.

Alfurqan, Alfurqan. Konsep Pendidikan Islam Pondok Pesantren Dan Upaya Pembenahannya. Padang: UNP Press, 2015.

Alfurqan, A., \& Harmonedi, H. 2017. Pandangan Islam Terhadap Manusia: Terminologi Manusia dan Konsep Fitrah serta Implikasinya dengan Pendidikan. Journal Educative: Journal of Educational Studies, 2(2), 129-144.

Aziz, Safrudin. "Pendidikan Spritual Berbasis Sufistik Bagi Anak Usia Dini Dalam Keluarga.” Dialogia: Jurnal Studi Islam Dan Sosial 15, no. 1 (1 Juni 2017): 13149. https://doi.org/10.21154/dialogia.v15i1.1188.

Celarent, Barbara. "The Modernist Muslim Movement in Indonesia, 1900-1942 by Deliar Noer.” American Journal of Sociology 118, no. 5 (1 Maret 2013): 1467 73. https://doi.org/10.1086/670524.

Daya, Burhanuddin. Gerakan pembaharuan pemikiran Islam: kasus Sumatera Thawalib. Tiara Wacana Yogya, 1990.

Dobbin, Christine. Islamic Revivalism in a Changing Peasant Economy/ : Central Sumatra, 1784-1847. Routledge, 2016. https://doi.org/10.4324/ 9781315398181.

Engkizar, Engkizar, Indah Muliati, Rini Rahman, dan Alfurqan Alfurqan. "The Importance of Integrating ICT Into Islamic Study Teaching and Learning Process." Khalifa Journal of Islamic Education 1, no. 2 (20 Januari 2018): 148-68.

Furqan, Al. "Islamic Education Values in Minangkabau Wedding Ceremony (Study of Traditional Mariage in Pauh, Padang, West Sumatera).” Al-Ta Lim Journal 23, no. 1 (12 Maret 2016): 88-94. https://doi.org/10.15548/jt.v23i1.166. 
Furqan, Al Furqan Al, dan Murniyetti Murniyeeti. "Profil Pendidik Dalam LingkaranTerminologi Ayat -Ayat Alquran." Islam Transformatif/ : Journal of Islamic Studies 1, no. 2 (6 Maret 2018): 191-202. https://doi.org/10.30983/ it.v1i2.474.

Goleman, D. 1996. Emotional intelligence. Why it can matter more than IQ. Learning, 24(6), 49-50.

Gumilar, G. 2015. Pemanfaatan Internet oleh Santri Pesantren Modern (Islamic Bo arding School). JIPSI-Jurnal Ilmu Politik dan Komunikasi UNIKOM, 4.

Hadler;, Jeffrey. Sengketa Tiada Putus: Matriart, Reformisme Islam, dan Kolonialisme di Minangkabau. Freedom Institute, 2010 . //perpustakaan.komnasham.go.id/ opackomnas/index.php?p=show_detail\&id=11097\& keywords $=$.

Hidayat,Teguh. 2016. Surau Syech Gadang Burhanuddin dan Surau Tinggi Calau, Kementerian Pendidikan Dan Kebudayaan Balai Pelestarian Cagar Budaya Sumatera Barat

Idawati, I., \& Hesti, H. 2019. Pengenalan Karakter Anak Usia Dini Melaui Smart Hafiz. In Prosiding Seminar Nasional STKIP PGRI Bandar Lampung (pp. 237248).

Kahn, Edited by Wendy Mee and Joel S. Questioning Modernity in Indonesia and Malaysia. NUS Press Pte Ltd, 2012. https://muse.jhu.edu/book/19358.

Lombard, Denys. "K. A. Steenbrink, Pesantrèn, Madrasah, Sekolah. Recente Ontwikkelingen in Indonesisch Islamonderricht, Meppel, 1974, 366 p." Annales. Histoire, Sciences Sociales 35, no. 3-4 (Agustus 1980): 852-53. https://doi.org/ 10.1017/S0395264900145573.

Meigalia, Eka. "Oman Fathurahman, Tarekat Syattariyah Di Minangkabau; Teks Dan Konteks. Jakarta: Prenada Media Group, École Française d’Extrême-Orient, Pusat Pengkajian Islam Dan Masyarakat (PPIM) UIN Jakarta, and KITLVJakarta, 2008, 185 Pp. [Seri Buku Pustaka Hikmah Disertasi (PhD) 1.] ISBN 978-979-3464-43-5. Price: IDR 45,000 (Soft Cover).” Wacana 12, no. 1 (28 Agustus 2010): 207-10. https://doi.org/10.17510/24076899-01201015.

Natsir, Mhd. "Peranan Surau Sebagai Lembaga Pendidikan Islam Tradisional Di Padang Pariaman Sumatera Barat (Surau Syaikh Burhanuddin).” Pedagogi: Jurnal Ilmu Pendidikan 12, no. 2 (30 November 2012): 39-46.

Roff, William R. "C. Snouck Hurgronje, Mekka in the Latter Part of the 19th Century. Translated by J. H. Monahan. Leiden, E. J. Brill, Photomechanical Reprint, 1970, Pp. vi + 309, Index, Plates, Plans. 42 Guilders." Journal of Asian and African Studies 7, no. 3-4 (1 Januari 1972): 331-33. https://doi.org/ $10.1163 / 156852172$ X01183.

Sanusi Latief, Muhammad. "Perkembangan Pemikiran Islam di Minangkabau." Panji Masyarakat, 1989, bag. 628.

Siregar, Muammar Kadafi. "Pondok Pesantren Antara Misi Melahirkan Ulama Dan Tarikan Modernisasi." Jurnal Pendidikan Agama Islam Al-Thariqah 3, no. 2 (16 November 2018): 16-27. https://doi.org/10.25299/ althariqah.2018.vol3(2).2263.

Suhailah Zain al-'Abidin Hammad, Ahmad. Mas'uliyah al-Usrah fi Tahhin al-Syabab 
min al- Irhab, Lajnah al-'ilmiyah li al-Mu'tamar al-Alami 'an Mauqif al-Islam min alIrhab. 2004, t.t.

Taufik Hidayat, Ahmad, dan Chairullah Chairullah. Bibliografi Karya Ulama Minangkabau Awal Abad Xx, Dinamika Intelektual Kaum Tua Dan Kaum Muda. Padang: Ko munitas Suluah, 2012.

Wimra, Z. (2020). Keterlibatan Tuanku dalam Pergesekan Identitas Adat, Agama, dan Negara di Minangkabau. Analisis: Jurnal Studi Keislaman, 20(1), 69-94.

Yatim, Badri,1999. Sejarah sosial keagamaan Tanah suci: Hijaz (Mekah dan Madinah) 1800-1925. Logos.

Zohar, Danah, dan Ian Marshall, 2001. Spiritual Intelligence: The Ultimate Intelligence. New edition edition. London: Bloomsbury Publishing PLC. 
